\title{
POTENCY OF SOLID WASTE OF PAPER MILL USING RECYCLE PAPER AS FUEL
}

\author{
Yusup Setiawan *, Sri Purwati, Krisna Aditya Wardhana, Aep Surahman, Reza Bastari Wattimena \\ Center for Pulp and Paper, Jl. Raya Dayeuhkolot No. 132, Bandung \\ * yusupsetiawan60@yahoo.com
}

Diterima : 12 Nopember 2012, Revisi akhir : 24 Desember 2012

\author{
POTENSI LIMBAH PADAT INDUSTRI KERTAS \\ BERBAHAN BAKU KERTAS BEKAS SEBAGAI BAHAN BAKAR
}

\begin{abstract}
ABSTRAK
Industri kertas menghasilkan limbah padat seperti limbah lumpur dan limbah reject. Jumlah limbah reject dari pengolahan kertas daur ulang bervariasi dari 5\% sampai 25\% tergantung pada kualitas serat dan proses yang digunakan di pabrik. Komposisi limbah reject terdiri dari gumpalan serat, potongan plastik dan foil. Salah satu keterbatasan dari limbah padat untuk energi adalah ruah dan kadar air-nya tinggi yang menyulitkan dalam penyimpanan, transportasi, dan penggunaannya. Untuk mengatasi keterbatasan ini diperlukan proses solidifikasi. Pembuatan pellet dari limbah padat industri kertas merupakan salah satu proses solidifikasi untuk memudahkan dalam penyimpanan, penanganan, dan pengangkutan limbah padat. Penelitian pemanfaatan limbah padat dalam bentuk pelet sebagai bahan bakar untuk energi telah dilakukan. Proses solidifikasi limbah padat pabrik kertas terdiri dari proses pengeringan, proses pencacahan dan proses pembuatan pellet. Pellet limbah padat industri kertas dan campuran dari batubara dan pellet limbah reject diuji untuk analisis proksimat, kadar mineral abu, kadar abu dan suhu fusi abu (AFT) untuk mengetahui potensi slagging dan fouling. Hasil menunjukkan bahwa limbah reject industri kertas mengandung nilai kalor tinggi $5.987 \mathrm{kalori} /$ gram dan rendah sulfur dan abu. Abu mengandung alkali total $\left(\mathrm{Na}_{2} \mathrm{O}\right.$ dan $\left.\mathrm{K}_{2} \mathrm{O}\right)$ rendah dan suhu deformasi awal tinggi (IDT) yaitu $1.193{ }^{\circ} \mathrm{C}$. Campuran dari batubara $95 \%$ dan pellet limbah reject $5 \%$ mengandung alkali total $\left(\mathrm{Na}_{2} \mathrm{O}\right.$ dan $\mathrm{K}_{2} \mathrm{O}$ ) rendah dan suhu deformasi awal tinggi (IDT) yaitu $1.315^{\circ} \mathrm{C}$. Hal ini menunjukkan potensi slagging dan fouling rendah bilamana limbah reject digunakan sebagai bahan bakar boiler.
\end{abstract}

Kata kunci: limbah padat, lumpur, reject, pelet, bahan bakar, slagging, fouling

\section{ABSTRACT}

The paper industry generates solid waste such as wastewater sludge and paper mill rejects. The rejects from recycled paper processing are varies from $5 \%$ to $25 \%$ dependent on the recovered fiber quality and process used in the mill. The composition of the rejects is consisted of fiber bundles, plastics pieces, foils and polystyrene containing large quantities of plastics. One of the limitations of solid waste for energy is bulky and high moisture content which is difficult to be stored, transported, and utilized. To overcome this limitation, it is needed a solidification process. Pelletizing of paper mill solid waste is one of solidification processes to ease in storing, handling, and transporting of solid waste. Experiment on solid wastes utilization in the pellet form as fuel has been carried out. Solidification process of paper mill solid waste is consisted of drying, shredding and pelletizing processes of solid waste. Pellet of paper mill solid waste and coal and pellet of combination of rejects waste were analyzed for their proximate, mineral content of ash and ash fusion temperature (AFT) to see slagging and fouling potency. The results shows that paper mill reject contain high calorific value of 5,987 calorie/gram and low content of sulphur and ash. Ash has low content of total alkali $\left(\mathrm{Na}_{2} \mathrm{O}\right.$ and $\left.\mathrm{K}_{2} \mathrm{O}\right)$ and high initial deformation temperature (IDT) of $1,193^{\circ} \mathrm{C}$. Mixed of $95 \%$ coal and $5 \%$ pellet of reject waste has low content of total alkali $\left(\mathrm{Na}_{2} \mathrm{O}\right.$ and $\left.\mathrm{K}_{2} \mathrm{O}\right)$ and high initial deformation temperature (IDT) of $1,315^{\circ} \mathrm{C}$. The result indicates low slagging and fouling potency of reject waste when it is utilized as a boiler fuel.

Keywords: solid waste, sludge, rejects, pellet, fuel, slagging, fouling 


\section{INTRODUCTION}

Paper industry is a significant user of energy in the form of electricity and heat to power machinery and to dry paper sheets (Miloud et al., 2012). This industry is a capital and resourceintensive industry contributing to environmental problems such as global warming, ecotoxicity, photochemical oxidation, acidification, nitrification, and solid wastes (Kuik, 2006). Paper industry generates solid waste such as wastewater treatment sludge and paper mill rejects. Landfilling is still the most popular method of disposal for waste water treatment sludge and paper mill rejects (William et al., 1994).

Paper mill rejects from recycled paper processing depending on the final product, the reject rate varies from $5 \%(\mathrm{w} / \mathrm{w})$ e.g. for used corrugated containers up to $25 \%(\mathrm{w} / \mathrm{w})$. Reject waste generally have high calorific value and low ash content (Miloud et al., 2012). The rejects from the pulping of recycled paper is consisted of fiber bundles, plastic pieces, foils and polystyrene containing large quantities of plastics depended on recycled paper grade. The option to use paper mill reject as a waste fuel for energy production has been recently considered in Japan and many European countries (Gavrilescu, 2008; Takenaka, 2012). Pelletizing as a solidification method to convert a combustible solid waste, which is normally land filled, into a useable fuel (William, 1994; Kuik, 2006). The advantages of densified of fuel pellets is low amount of dust, free flowing fuel, ease storage and transportation, and uniformity of size (Samson et al., 2000). Recent years have seen high demand boilers using wastederived fuels such as wood biomass, plastics, refuse paper and plastic fuel (RPF), sludge, and other recycled materials to substitute of fossil fuels. The circulating fluidized bed boiler (CFB) is a boiler, which is applicable to these diverse waste-derived fuels (Nakao et al., 2011).

Most of paper industry use power plant boilers for steam generation and electricity production. A large percentage of power plant boilers use coal as a fuel. Coal characteristics affect the performance of the plant including electricity production capacity and waste disposal requirements, and overall this affects the environment. The most problematic and trouble some effect of coal is the creation of sticky and hardened deposits on furnace or convection surfaces of boilers. Fuel quality, boiler operation and design properties of boilers also have impacts on the deposition (Ana et al., 2005). Coals contain different mineral material in various forms. During combustion, the mineral matter is transformed into fly ash, which is deposited on heat transfer surfaces of boilers. Accumulations of these deposits are known as slagging or fouling problem (Ana et al., 2005). When the deposition of ash on furnace walls, mainly in the radiant section, in a highly viscous state and forms a liquid layer, it is called slagging. When the deposit is built up by condensed materials, forming a dry deposit, in the convective section, it is called fouling (Ana et al., 2005; Hare et al., 2010). Deposits formation on heat transfer surfaces is one of the biggest problems for all solid fuel fired boilers (Ana et al., 2005).

In this paper, pellet making process from recycled paper mill solid waste is described. Characterization of this pellet and coal related to potency of slagging is assessed.

\section{MATERIALS AND METHODS}

\section{Materials}

Reject waste from hydra pulper and sludge waste from belt filter press used in the experiment were taken from recycled paper mill producing corrugating medium and kraft liner in the amount of around 100 ton/day. This paper mill use recycle paper such as carton and core as raw material. Coal used as boiler fuel of this paper mill was also characterized. Reject waste has moisture content about $40-50 \%$ and sludge waste has moisture content about $70-75 \%$. Characteristics of reject waste, sludge waste, and coal is presented in Table $1-4$.

\section{Methods}

Pressing of reject waste in press machine to remove water content as much as possible is the first handling of reject waste. It is then dried by solar drying up to the moisture content of $\leq 10 \%$. Metal and glass materials were removed from dried reject waste manually. Dried reject waste was shredded by shredded machine having screen hole of around $4 \mathrm{~mm}$. Pelletizing of $100 \%$ shredded reject waste and mixed of $80-95 \%$ shredded reject waste and $5-20 \%$ sludge waste is done in pellet machine which can result pellet with the diameter of $10 \mathrm{~mm}$ and the length of around $10-15 \mathrm{~mm}$. Pellet of reject waste and sludge waste, and coal are analyzed for parameters air dried moisture, 
ash, fixed carbon, calorific value, sulphur and Ash Fusion Temperature (AFT). These parameters were measured according to ASTM method. Parameter of volatile matter (VM) was measured according to ISO 562:1998 method. Mineral content of ash was also measured by Atomic Absorption Spectrofotometric (AAS) method.

\section{RESULTS AND DISCUSSIONS}

\section{Solid Waste in Paper Mill}

Reject waste from hydra pulper and sludge waste from belt filter press produced by corrugating medium and kraft liner paper mill are in the amount of $4-5$ ton/day and $1.5-2$ ton/day, respectivelly. Reject waste contain big portion of plastics, fiber bundles and small portion of metal. While sludge waste contain fine cellulose fiber and anorganic substances. The percentage of reject waste to paper product is $4-5 \%$ and this reject waste is just burn in insinerator. In supplying of steam for paper production, this paper mill use circulating fluidized bed (CFB) boiler with the coal consumption of $40-50$ ton/ day or $0.4-0.5$ ton coal per ton paper product. It reveals that the amount of wet reject waste produced is $10 \%$ of coal consumption or $5 \%$ of coal consumption for dried reject waste. If reject waste can be use as boiler fuel, paper mill can eliminate cost for reject waste handling and reduce cost for coal purcashing of around $5 \%$.

\section{Pelletizing Process of Reject Waste and Sludge Waste}

Due to reject waste still high moisture content, it has to press prior in press machine to remove the water content as much as possible and to shorten drying time of reject waste. Metal and glass materials must be removed from dried reject waste before shredding to avoid the damaged of shredder knife. Reject waste and sludge waste were dried by solar drying up to the moisture content of $\leq 10 \%$. Dried reject waste was shredded by shredding machine having screen hole of around $4 \mathrm{~mm}$ resulting shredded reject waste. Shredded reject waste is fed into the pelleting cavity, where it is directed equally on either side of the edges, formed by the rollers and the inside face of the die. The rollers turn as the die rotates, forcing the material through the die holes by the extreme pressure caused by the wedging action. As the pellet extruded, adjustable knives cut them to the desired length (Samson et al., 2000).

Pelletizing is done by variying composition such as $100 \%$ shredded reject waste and mixed of $80-95 \%$ shredded reject waste and $5-20 \%$ sludge waste. Temperature of pellet can reach up to $70-80^{\circ} \mathrm{C}$ during pelletizing process. In this temperature, plastics will begin to become soft, sticky and combine each other to form a strongth bond. At the moisture content of shredded reject waste of $\leq 10 \%$, compact and hard pellet with the diameter of $10 \mathrm{~mm}$ and the length of around $10-15 \mathrm{~mm}$ can be obtained. When the moisture content of shredded reject waste of $>$ $30 \%$, uncompact pellet is resulted. In this cases, evaporation of water content in reject waste is dominant and softening of plastics to form a strongth bond is not occur yet. Solidification process of reject waste through pellet form as a fuel has some advantages such easy storage and transport, uniform size, low dust content, higher density than raw materials and ease in feeding into the boiler.

\section{Characterization of Solid Waste Pellet and Coal}

Pellet of $100 \%$ reject waste, $100 \%$ sludge waste and mixture of $80-95 \%$ reject waste and 5 - $20 \%$ sludge waste, and coal were characterized for parameters including calorific value, proximate analysis and fuel ratio.

\section{Calorific Value}

Calorific value is one of parameters determining the quality of coal. There are four quality types that is low quality of $<5,100 \mathrm{cal} / \mathrm{g}$, medium quality of $5,100-6,100 \mathrm{cal} / \mathrm{g}$, high quality of $6,100-7,100 \mathrm{cal} / \mathrm{g}$ and very high quality of $>7,100 \mathrm{cal} / \mathrm{g}$ (Tekmira, 2006). The calorific value of pellet made from reject waste, sludge waste, and mixture reject waste and sludge waste, and coal is presented in Table 1 . It show that calorific value of coal used as CFB boiler fuel of this paper mill is $5,365 \mathrm{cal} / \mathrm{g}$ which is categorized in medium quality. Sludge waste contain the lowest calorific value $(2,962 \mathrm{cal} / \mathrm{g})$. The highest calorific value content is given by $100 \%$ reject waste $(5,987 \mathrm{cal} / \mathrm{g})$. Mixture of 90 $95 \%$ reject waste and $5-10 \%$ sludge waste still has high calorific value $(5,614-5,810 \mathrm{cal} / \mathrm{g})$ and 
it is still higher than coal. These pellet of reject waste and the mixture have calorific value in medium quality. While mixture of $80 \%$ reject waste and $20 \%$ sludge waste only has the calorific value of $5,071 \mathrm{cal} / \mathrm{g}$ which is lower than calorific value of coal. According to their calorific value, it is possible to use pellet of $100 \%$ reject waste and mixture of $90-95 \%$ reject waste and $5-10 \%$ sludge waste to be mixed with coal as boiler fuel. Possible composition of mixture pellet of $100 \%$ reject waste or mixture of $90-95 \%$ reject waste and $5-10 \%$ sludge waste and coal is the ratio of $5 \%$ and $95 \%$, respectivelly.

Table 1. Calorific Value of Coal, Pellet of Reject Waste, Sludge Waste, and Mixture of Reject Waste and Sludge Waste

\begin{tabular}{ccc}
\hline No & Materials & Calorific Value \\
\hline 1 & Sludge waste $(100 \%)$ & $2,962 \mathrm{cal} / \mathrm{g}$ \\
2 & Reject waste $(100 \%)$ & $5,987 \mathrm{cal} / \mathrm{g}$ \\
3 & Mixture reject waste $(95 \%)+$ & $5,810 \mathrm{cal} / \mathrm{g}$ \\
& sludge waste $(5 \%)$ & \\
4 & Mixture reject waste $(90 \%)+$ & $5,614 \mathrm{cal} / \mathrm{g}$ \\
& sludge waste $(10 \%)$ & $5,071 \mathrm{cal} / \mathrm{g}$ \\
5 & Mixture reject waste $(80 \%)+$ & \\
& sludge waste $(20 \%)$ & $5,365 \mathrm{cal} / \mathrm{g}$ \\
\hline
\end{tabular}

Besides according to calorific value parameter, assessment of solid waste utilization as boiler fuel which is mainly for proximate analysis, sulphur content and potency of slagging and fouling should be done.

\section{Proximate Analysis}

Proximate analysis of coal is to determined by moisture content, ash, volatile matter and fixed carbon (Tekmira, 2006). Results of proximate analysis of pellet of sludge waste, reject waste, mixture reject waste and sludge waste, and coal are presented in Table 2 .

It shows that $100 \%$ reject waste has the highest volatile matter content. But it has the lowest of fixed carbon content. While the pellets made from sludge waste had the highest ash content. The high ash content of sludge waste is greatly affects to the increasing of ash content of pellets of mixture of reject waste and sludge waste. The greater the percentage of sludge waste addition, the higher ash content of pellets in it mixtures. Increasing the addition of sludge waste into reject waste cause the increasing of ash and fixed carbon contents of pellets of mixture of reject waste and sludge waste. On the other hand, it decreases the volatile matter content of pellets of mixture of reject waste and sludge waste. Sulphur content of coal is the highest $(0.31 \%)$. While sulphur content of pellets made from $100 \%$ reject waste is the lowest $(0.08 \%)$. The addition of sludge waste into reject waste mixtures increase sulphur content of pellets produced. The addition of waste sludge up to $20 \%$ into $80 \%$ reject the waste still produce pellets with sulphur content lower than coal. The use of reject waste or the mixture with sludge mixed into coal as boiler fuel will not lead in increasing of $\mathrm{SO}_{2}$ content in boiler emission.

Table 2. Proximate and Sulphur Analysis of Pelletized of Waste and Coal

\begin{tabular}{|c|c|c|c|c|c|c|}
\hline \multirow[b]{2}{*}{ No } & \multirow[b]{2}{*}{ Materials } & \multicolumn{5}{|c|}{ Parameters } \\
\hline & & $\begin{array}{l}\text { Air dried } \\
\text { Moisture }\end{array}$ & Ash & $\begin{array}{l}\text { Volatile } \\
\text { Matter }\end{array}$ & $\begin{array}{l}\text { Fixed } \\
\text { Carbon }\end{array}$ & Sulphur \\
\hline 1 & Sludge waste (100\%) & $7.91 \%$ & $25.1 \%$ & $57.38 \%$ & $9.55 \%$ & $0.14 \%$ \\
\hline 2 & Reject waste $(100 \%)$ & $3.93 \%$ & $7.1 \%$ & $81.93 \%$ & $6.98 \%$ & $0.08 \%$ \\
\hline 3 & $\begin{array}{l}\text { Mixture of reject waste }(95 \%)+\text { sludge } \\
\text { waste }(5 \%)\end{array}$ & $3.01 \%$ & $7.94 \%$ & $81.66 \%$ & $7.39 \%$ & $0.10 \%$ \\
\hline 4 & $\begin{array}{l}\text { Mixture of reject waste }(90 \%)+\text { sludge } \\
\text { waste }(10 \%)\end{array}$ & $3.86 \%$ & $10.4 \%$ & $79.60 \%$ & $7.66 \%$ & $0.24 \%$ \\
\hline 5 & $\begin{array}{l}\text { Mixture of reject waste }(80 \%)+\text { sludge } \\
\text { waste }(20 \%)\end{array}$ & $4.33 \%$ & $10.95 \%$ & $76.68 \%$ & $8.04 \%$ & $0.26 \%$ \\
\hline 6 & Coal & $19.66 \%$ & $5.18 \%$ & $37.46 \%$ & $37.70 \%$ & $0.31 \%$ \\
\hline
\end{tabular}




\section{Fuel Ratio (FC/VM)}

The calculation results of the fuel ratio of pellets from rejects waste, sludge waste, mixed reject waste and sludge waste, and coal is given in Table 3. Carbon and volatile matter contents of the fuel is very influential at the ignition properties of the fuel during combustion process, and the amount of carbon burning. Comparison of carbon content to volatile matter content referred to the fuel ratio (carbon content/volatile matter content). When the ratio of the fuel value is lower than 1.2, it would result in the ignition of good fuel burning with the increasing of burning speed. Conversely, if fuel ratio is higher than 1.2, it would cause a lot of unburned carbon.

Table 3. Fuel ratio (FC/VM) of pellet of rejects waste, sludge waste, mixture of reject waste and sludge waste and coal

\begin{tabular}{ccc}
\hline No & Materials & Fuel ratio \\
\hline 1 & Sludge waste (100\%) & 0.166 \\
2 & Reject waste (100\%) & 0.085 \\
3 & $\begin{array}{c}\text { Mixture of reject waste (95\%) } \\
+ \text { sludge waste }(5 \%)\end{array}$ & 0.090 \\
& $\begin{array}{c}\text { Mixture of reject waste (90\%) } \\
+ \text { sludge waste (10\%) }\end{array}$ & 0.096 \\
& $\begin{array}{c}\text { Mixture of reject waste (80\%) } \\
+ \text { sludge waste (20\%) }\end{array}$ & 0.105 \\
6 & Coal & 1.001 \\
\hline
\end{tabular}

The fuel ratio of all pellets made from rejects waste, sludge waste, mixed of reject waste and sludge waste, and coal is lower than 1.2. It shows that the combustion ignition process of fuel will be good. The fuel ratio of pellets made from rejects waste, sludge waste, mixed of reject waste and sludge waste is smaller than coal. This will cause that the ignition property and combustion velocity of pellets would be faster than coal. It also shows that the pellets from reject waste will be faster exhaustion in the combustion process. Additions of reject waste pellets in coal will be very useful especially during the initial burning of coal in boiler. It will be faster and shorter.

\section{Assessment for Slagging and Fouling}

The analysis results of the ash mineral content and ash fusion temperature (AFT) of pellets made from rejects waste, coal and mixture of coal and reject waste is shown in Table 4. This value of the ash mineral content is very useful for evaluating of fuel to slagging and fouling potency in the boiler during the combustion process. As it is known that the slagging and fouling is an attachment and accumulated phenomenon of melted mineral ash of fuel in the pipes of heat (heat exchanger tube) or boiler wall. Both phenomena are very serious which can have a major impact on boiler operations, such as heat conduction problems, decreased efficiency boilers, and clogging pipes (Maphala, 2008). These phenomenons are mainly influenced by the ash mineral content such as $\mathrm{Na}_{2} \mathrm{O}, \mathrm{K}_{2} \mathrm{O}, \mathrm{Fe}_{2} \mathrm{O}_{3}$ and $\mathrm{CaO}$ and ash fusion temperature (AFT). $\mathrm{Na}_{2} \mathrm{O}$ and $\mathrm{K}_{2} \mathrm{O}$ compound in ash will form a compound having a low melting point when bonded with other elements. Increasing of slagging tendency will also be followed by the increasing of fouling tendency which is in accordance with the alkali content in ash. Quality standard of coal used in Japan and boiler makers in Europe and United State of America has set $\mathrm{Na}_{2} \mathrm{O}$ content of $<3 \%$, total alkali content $\left(\mathrm{Na}_{2} \mathrm{O}\right.$ and $\left.\mathrm{K}_{2} \mathrm{O}\right)$ of $<3 \%$, $\mathrm{CaO}$ content of $<20 \%$, and $\mathrm{Fe}_{2} \mathrm{O}_{3}$ content of $<15 \%$ (Maphala, 2008 ). From these data, it shows that coal used as fuel boiler in the paper industry, pellets of $100 \%$ reject waste and pellets of mixture of coal $(95 \%)+$ reject waste $(5 \%)$ has low potency for slagging and fouling phenomena in boiler during the combustion process.

Apart from ash mineral content data to predict the potential slagging and fouling in the boiler during combustion is required AFT test. On AFT testing is observed initial deformation temperature i.e. the temperature at which the ash cone end first softened, softening temperature i.e. temperature when the height of the cone equal to the width of the cone, hemisphere temperature i.e. temperature when the height of the cone is half the width of the cone, and flow temperature i.e. temperature when the height of the sample is about $1.5 \mathrm{~mm}$ (Maphala, 2008). From Table 4, it shows that pellets from $100 \%$ reject waste have a softening temperature is quite high $\left(>1,200^{\circ} \mathrm{C}\right)$. The addition of $5 \%$ pellets of $100 \%$ reject waste into coal, although it has slightly lower softening temperature, but it still have a high softening temperature $\left(>1,300^{\circ} \mathrm{C}\right)$. Based on the field survey in some paper industry, the furnace temperature of circulating fluidized bed (CFB) boiler during combustion processes is generally around $900^{\circ} \mathrm{C}$. In addition, some literature reported that the 
Table 4. Characteristics of Ash Mineral Content and Ash Fusion Temperature (AFT) of Pelletized Waste and Coal

\begin{tabular}{lccc}
\hline & Reject waste $00 \%)$ & Mixture of coal (95\%) + reject waste (5\%) & Coal \\
\hline Ash mineral content: & & & \\
\hline$-\mathrm{Fe}_{2} \mathrm{O}_{3}$ & $11.73 \%$ & $6.98 \%$ & $7.71 \%$ \\
$-\mathrm{CaO}$ & $19.35 \%$ & $7.95 \%$ & $8.01 \%$ \\
$-\mathrm{MgO}$ & $2.20 \%$ & $1.08 \%$ & $1.02 \%$ \\
$-\mathrm{Na} O$ & $0.70 \%$ & $0.55 \%$ & $0.97 \%$ \\
$-\mathrm{K}_{2} \mathrm{O}$ & $1.45 \%$ & $0.55 \%$ & $0.45 \%$ \\
$-\mathrm{SiO}_{2}$ & $35.20 \%$ & $43.28 \%$ & \\
$-\mathrm{Al}_{2} \mathrm{O}_{3}$ & $59.10 \%$ & $30.60 \%$ & \\
\hline
\end{tabular}

\begin{tabular}{lccc}
\hline Ash fusion temperature $(\mathrm{AFT})$ : & & & \\
\hline a). Oxidizing Atmosphere : & & & 1,333 \\
- Deformation Temperature $\left({ }^{\circ} \mathrm{C}\right)$ & 1,203 & 1,343 & 1,495 \\
- Spherical Temperature $\left({ }^{\circ} \mathrm{C}\right)$ & 1,253 & 1,353 & $>1,500$ \\
- Hemisphere Temperature $\left({ }^{\circ} \mathrm{C}\right)$ & 1,273 & 1,400 & $>1,500$ \\
- Flow Temperature $\left({ }^{\circ} \mathrm{C}\right)$ & 1,325 & & \\
b). Reducing Atmosphere & & 1,315 & 1,415 \\
- Deformation Temperature $\left({ }^{\circ} \mathrm{C}\right)$ & 1,193 & 1,325 & 1,460 \\
- Spherical Temperature $\left({ }^{\circ} \mathrm{C}\right)$ & 1,243 & 1,338 & 1,470 \\
- Hemisphere Temperature $\left({ }^{\circ} \mathrm{C}\right)$ & 1,258 & 1,398 & 1,495 \\
- Flow Temperature $\left({ }^{\circ} \mathrm{C}\right)$ & 1,300 & & \\
\hline
\end{tabular}

temperature in the entire furnace of circulating fluidized bed (CFB) boiler is not exceeding $1,000^{\circ} \mathrm{C}$ (Thomas et.al., 1995; Nakao, 2011; Yoshihisa et.al., 2005). Comparing the operating temperature of the boiler in the paper industry to the initial deformation temperature and softening temperature of pellets from $100 \%$ reject waste; it indicates that the initial deformation temperature and softening temperature of pellets from $100 \%$ reject waste is still above the operating temperature of boiler used in the paper industry. This means that softening of ash mineral of pellet from reject waste is not taken place yet so that slagging and fouling phenomena will not be occurred in boiler.

\section{CONCLUSION}

Pelletizing process of solid waste of paper mill (reject waste and sludge waste) is consisted of drying, shredding, and pelletizing processes. Pellet of reject waste have calorific value in medium quality. The use of reject waste or the mixture with coal as boiler fuel will not lead in increasing of $\mathrm{SO}_{2}$ content in boiler emission. Additional of $5 \%$ pellets of reject waste into $95 \%$ coal as boiler fuel has low potency for slagging and fouling phenomena in boiler during the combustion process. Utilization of reject waste as coal substitution for boiler fuel of paper mill could eliminate cost for reject waste handling.

\section{REFERENCES}

Ana Abel Tortosa-Masiá, Falk Ahnert, Harmut Spliethoff, Jean Claude Loux, and Klaus R. G. Hein. 2005 Slagging and Fouling in Biomass Co-Combustion. Thermal Science, Vol. 9, No. 3, $85-98$.

Fluidized bed firing technology. Unit 26. www. poisson.me.dal.ca/. accessed date on December 10, 2012

Gavrilescu D., Energy from Biomass in Pulp and Paper Mills. 2008, Environmental engineering and Management Journal, Vol.7, No.5, 537546. 
Hare, N., Rasul, M.G., Moazzem, S. 2010, A Review on Boiler Deposition/Foulage Prevention and Removal Techniques for Power Plant. Recent Advances in Energy and Environment Journal, ISSN: 1790-5095. ISBN: 978-960-474-159-5:217-222.

Kuik, Onno. 2006. Environmental innovation Dynamic in the Pulp and Paper Industry. European Commission, DG Environment. Institute for Environmental Studies Vrije Universiteit De Boelelaan, Amsterdam, the Netherlands. November 30

Maphala, Tshifhiwa. 2008. Identification of sintering and slagging materials: Characterization of coal, ash and noncoal rock fragments. School of Chemical and Metallurgical Engineering, Faculty of Engineering and the Built Environment, University of the Witwatersrand, Johannesburg.

Miloud Oudi, John Brammer, Andreas Hornung, Martin Kay. 2012. Waste to Power. Tappi Journal, Vol. 11, No. 2: 55-64.

Nakao Nobuyuki., Shimamoto Hiroyuki. 2011. CFB Combustion Control System for Multiple Fuels. JFE Technical Report, No. 16
Pusat Litbang Teknologi Mineral dan Batubara (Tekmira). Batubara Indonesia. 2006. www. tekmira.esdm.go.id. accessed date on 17 October 2012.

Samson, R., Duxbury, P.,Drisdelle, M.,Lapointe, C. Assessment of Pelletized Biofuels. 2000. www.pelletstove.com. accessed date on September 19, 2012.

Takenaka, Motoyasu. Waste Plastic Solid Fuel: RPF (Refused Paper and Plastic Fuel), http:/ www.jrpf.gr.jp. Retrieved at February 8, 2012. Thomas R. Miles, Larry L. Baxter, Richard W. Bryers, Bryan M. Jenkins, Laurence L. Oden. Alkali Deposit. 1995. Summary Report for National Renewable Energy Laboratory US Department Energy.

William E. Nichol., Louis N. Flanders. 1994. An Evaluation of Pelletizing Technology or How to Convert Trash to Fuel. TAPPI Proceeding of Engineering Conference, 915-921.

Yoshihisa Arakawa, Toshiyuki Sakai, Shigeharu Kokuryo, TatsuoYokoshiki, Hitoji Yamada, Isao Torii. 2005. Design and Operational Performance of RPF Fired Circulating Fluidized Bed boiler. Mitsubishi Heavy Industries, Ltd. Technical Review. Vol. 42, No.3 